Огляди літератури, оригінальні дослідження, погляд на проблему

УДК 616.381-002.1-06:611.136.41/.7

DOI

\title{
ФУНКЦІОНАЛЬНІ ОСОБЛИВОСТІ СУДИННОГО РУСЛА НИРОК ТА ПЕЧІНКИ ПРИ ГОСТРОМУ РОЗЛИТОМУ ПЕРИТОНІТІ ТА ЙОГО УСКЛАДНЕННЯХ
}

\section{ДВНЗ «Тернопільський державний медичний університет імені І. Я. Горбачевського МОз України»}

РЕЗЮМЕ. У роботі представлено огляд морфофункціональних проявів реакції кровоносних судин нирок і печінки у динаміці розвитку гострого розлитого перитоніту та його ускладнень.

Виявлено особливості функціональних змін судинного русла нирок та печінки, які виникають внаслідок токсичних впливів продуктів обміну, що поступають у кровоносне русло із черевної порожнини. Відзначено підвищення внутрішньочеревного тиску, яке має місце при прогресуванні гострого розлитого перитоніту, як одну з основних причин виникнення розладів загальної і органної гемодинаміки.

КЛЮчОВІ СЛОВА: перитоніт, судини, нирки, печінка.

Загальновідомо, що діяльність будь-якого органа неможлива без адекватної доставки поживних речовин і своєчасного видалення продуктів обміну, чим постійно і займається кровоносна система. Тому проблема утворення і росту судин $\epsilon$ однією з найважливіших у біології і патології людини [1].

Вивченню всіх ланок судинного русла присвячені фундаментальні роботи провідних морфологів $[2,3]$. Особлива, а інколи унікальна морфологічна організація структур судинного русла ряду органів забезпечують їх багатофункціональність. До таких органів, без усяких сумнівів, слід віднести печінку та нирки [4]. Наявність у печінці чотирьох компонентів судинного русла (артеріальних, портальних, венозних і лімфатичних судин), їх взаємовідношення з жовчними ходами і клітинами паренхіми - все це обумовлює унікальність будови найбільшої залози травного тракту ссавців і багатогранність їі функціональної діяльності.

Відомо, що у внутрішньоутробному періоді онтогенезу формуються всі органи і системи, які визначають становлення механізмів пристосування до умов постнатального життя. Розвиток органів обов'язково включає етап вростання (або утворення in situ) кровоносних судин. Ці процеси васкуляризації тонко скоординовані гістогенезом і органогенезом. Мікроциркуляторне кровоносне русло, яке включає, разом з капілярами, шляхи притоку - артеріоли і прекапілярні артеріоли, і шляхи відтоку крові, що представлені численними венулами, $\epsilon$ тим субстратом, де реалізується транспортна функція серцево-судинної системи і забезпечується транскапілярний обмін газів. Гемомікроциркуляція в органах починається саме там, де формуються структурно-функціональні одиниці, які включають всі компоненти гемомікроциркуляторного русла, і де капіляри структурно об'єднані у єдиний функціональний блок, або модуль, що обслуговує гістофізіологічний регіон органа $[5,6]$. Клініко-морфологічні дослідження проблем гемомікроциркуляції служать зближенню досягнень фундаментальної науки і клінічної практики. Проте, не дивлячись на широкий фронт і клінічних, і морфологічних досліджень, вивчення особливостей гемомікроциркуляції внутрішніх органів, зокрема нирок та печінки, при гострому розлитому перитоніті ще далеке від завершення. Стан судинних систем різноманітних органів $\epsilon$ визначальним для їх структури і функції, тому встановлення характеру перебудови і особливостей ремоделювання судин за умов порушеної гемоциркуляції $є$ одним із пріоритетних завдань сучасної морфології.

Гостра недостатність печінки і нирок або гепаторенальний синдром (ГРС) $\epsilon$ дуже частим компонентом синдрому поліорганної недостатності (СПОН) у пацієнтів із сеписом, що необхідно мати на увазі при підході до лікування таких станів [7].

Дані експериментальних і клінічних досліджень дають підставу припустити, що одним із ключових механізмів у патогенезі ГРС, який розвивається у пацієнтів з абдомінальним сепсисом, $\epsilon$ виражена системна вазодилатація в поєднанні з вазоконстрикцією спланхнічної ділянки із наступною гіпоксією тканин, що може стимулювати гіпофільтрацію нирок і ретенцію рідини в паренхіматозних органах, порушення печінкового кровотоку з розвитком недостатності печінки.

Згідно з найпоширенішими у наш час уявленнями, до регуляції руху крові по артеріях має відношення, в першу чергу, їх тонус, а також різні види замикаючих структур, скорочення і розслаблення яких відображається на пропускній спроможності судин, а отже - на інтенсивності органного кровотоку.

У клінічній та експериментальній медицині за рядом досліджень встановлено факт впливу портальної гіпертензії на спланхнічний та органний кровотік, а також позитивний вплив корекції пор- 
Огляди літератури, оригінальні дослідження, погляд на проблему

тальної гемодинаміки на кровообіг у хірургічних хворих. Розлади загальної і органної гемодинаміки закономірно виникають і при перитоніті. Однією із причин їх виникнення може бути підвищення внутрішньочеревного тиску, яке має місце при прогресуванні гострого розлитого перитоніту.

Компресія крупних судин при цьому визначає зміни центральноїгемодинаміки. Пряма дія підвищеного внутрішньочеревного тиску на нижню порожнисту вену призводить до значного зниження венозного повернення до серця [8]. Зміщення при цьому діафрагми у бік грудної порожнини також призводить до підвищення тиску в ній, посилюючи тим самим зниження венозного повернення; крім того відбувається механічна компресія серця і магістральних судин, i, як наслідок, - підвищення тиску в системі малого кола кровообігу. На початкових стадіях серцевий викид (СВ) може не змінюватися або навіть дещо підвищуватися унаслідок підвищення об'єму циркулюючої крові за рахунок зниження спланхнічного кровотоку. Однак пізніше, не дивлячись на компенсаторну тахікардію, СВ прогресивно знижується.

Дані спостереження наочно демонструють неможливість прогнозування змін артеріального тиску (АТ), котрий може не змінюватися або варіювати в широкому діапазоні.

Збільшення загального периферійного судинного опору прямо пропорційне величині інтраабдомінальної гіпертензії (ІАГ), що, мабуть, пов'язане з прямим механічним стисненням більшої частини судин і відповідною рефлекторною реакцією на зниження СВ.

Центральний венозний тиск (ЦВТ) у даних умовах, як і тиск заклинювання легеневої артерії (ТЗЛА), часто помітно підвищуються з одночасним зниженням кінцевого об'єму діастоли і підвищенням кінцевого тиску діастоли. В той же час зміна цих показників достовірно не відображає ні стану серцевої діяльності, ні ступеня гіповолемії. Більш інформативними методами діагностики центральної гемодинаміки в даній ситуації $є$ вимірювання СВ, серцевих об'ємів і індексів.

Гемодинамічний симптомокомплекс, що розвивається унаслідок підвищення тиску в черевній порожнині, в кінцевому результаті також призводить до розвитку поліорганної недостатності, будучи одним з її основних патогенетичних механізмів.

Щодо конкретних органів, то на початкових стадіях розвитку СІАГ (синдрому інтраабдомінальної гіпертензії) порушення функції нирок не $\epsilon$ пов'язаним із зниженням СВ, а скоріше $\epsilon$ наслідком прямої компресії паренхіми і судин нирок. Підвищення ниркового судинного опору при цьому призводить до зниження ниркового кровотоку і швидкості гломерулярної фільтрації.
Значний внесок у розвиток гострої ниркової недостатності можуть робити гормональні зрушення: підвищення секреції антидіуретичного гормону, реніну і альдостерону. Зниження венозного повернення до серця, як відомо, також призводить до зменшення секреції натрійуретичного пептиду передсердя.

Вважається, що зниження гломерулярної фільтрації настає при ІАГ більшій за 10-15 мм рт. СТ., а анурія розвивається при ІАГ більшій за 30 мм рт. Ст.

У основі місцевих патофізіологічних змін в органах черевної порожнини також лежить прямий, безпосередній вплив високого тиску, зокрема на порожнисті органи шлунково-кишкового тракту і портокавальну систему [9]. Компресія тканин і судин у таких випадках веде до порушення мікроциркуляції і тромбоутворення в дрібних судинах, ішемії кишкової стінки, її набряку з розвитком внутрішньоклітинного ацидозу, що, у свою чергу, призводить до транссудації і ексудації рідини, посилює ІАГ, утворюючи хибне коло. Ці порушення маніфестують при підвищенні тиску вже до 15 мм рт. ст. [10].

При збільшенні внутрішньочеревного тиску до 25 мм рт. ст. розвивається ішемія кишкової стінки, яка призводить до транслокації бактерій і їх токсинів у мезентеріальний кровотік і лімфовузли $[11,12]$.

Зміна лімфодинаміки по грудній лімфатичній протоці аж до її повного припинення після досягнення внутрішньочеревного тиску 30 мм рт. ст. призводить до подальшого збільшення інтраа6домінального об'єму і, як наслідок, до ІАГ.

Зниження СВ, олігурія, а також масивна інфузійна терапія можуть призвести до додаткового накопичення рідини в інтерстиціальному просторі, набряку кишечника і підвищення ІАГ, замикаючи порочне коло. На тканинному рівні це виявляється зниженням доставки кисню, гіпоксією, ішемією, розвитком анаеробного шляху метаболізму з виділенням біологічно активних речовин, медіаторів неспецифічного запалення i вазоактивних субстанцій, таких як інтерлейкіни, серотонін, гістамін і інші, збільшується проникність ендотелію, набряк інтерстицію, що посилює ішемію і трансмембранний транспорт, несприятливо відображаючись на спроможності міжкишкових анастомозів і загоєнні післяопераційних ран. Ці неспецифічні зміни розвиваються раніше від клінічно помітних проявів СІАГ.

Разом з тим, враховуючи такі особливості печінкових та ниркових вен як тонкостінність і відсутність у них клапанів, подвійне кровопостачання печінки, детальне вивчення питання регуляції кровотоку в цих органах набуває особливого значення. Адекватна оцінка виявлених змін має 
Огляди літератури, оригінальні дослідження, погляд на проблему

важливе клінічне значення, так як може скласти основу не тільки для оцінки ступеня тяжкості па- тологічного процесу, а й допоможе визначити обсяг і зміст лікувальних заходів.

\section{ЛІТЕРАТУРA}

1. Ertel $W$. Incidence and clinical pattern of the abdominal compartment syndrome after "damage-control" laparotomy in 311 patients with severe abdominal and/or pelvic trauma / W. Ertel, A. Oberholzer, A. Platz [et al.] // Crit. Care Med. - 2000. - Vol. 28. - P. 1747-1753.

2. Берестень Н. Ф. Состояние артериального кровообращения печени при сердечной недостаточности и портальной гипертензии / Н. Ф. Берестень, О. Н. Нельга // Медицинский журнал "SonoAce-International". 2001. - № 8. - С. 38-42.

3. Бєляков О. В. Зміни реґіонарного кровообігу в найближчому післяопераційному періоді у хірургічних хворих з портальною гіпертензією / О. В. Бєляков, М.В.Руденко, Ю. В. Грубнік [та ін.] // Досягнення біології та медицини. - 2004. - № 1 (3). - С. 76-79.

4. Ющак М. В. Реакція нирок на дегідратацію організму середнього ступеня / М. В. Ющак, Я. І. Федонюк, А. В. Гантімуров [та ін.] // Збірник матеріалів підсумкової науково-практичної конференції «Здобутки клінічної та експериментальної медицини», 17 червня 2010 року. Тернопіль : Укрмедкнига, 2010. - С. 167.

5. Ангиогенез / В. В. Куприянов, В. А. Миронов, А. А. Миронов, О. Ю. Турина. - М. : НИО «Квартет», 1993. $-176 \mathrm{C}$.
6. Куприянов В. В. Старые и новые концепции ангиогенеза и васкулогенеза / В. В. Куприянов // Морфология. - 1998. - № 113, Т. 3. - С. 67.

7. Алексеев С.А. Абдоминальный хирургический сепсис / С. А. Алексеев. - Мн. : Юнипак, 2005-256 с.

8. Oettgen P. Transcriptional regulation of vascular development / P. Oettgen // Circ. Res. - 2001. - Vol. 89, № 5. - P. 380-388.

9. Kitano Y. Influence of increased abdominal pressure on steady-state cardiac performance / Y. Kitano, M. Takata, N. Sasaki [et al.] // J. Appl. Physiol. - 1999. № 86. - P. 1651-1656.

10. Fujimura N. Alteration in diaphragmatic contracility du ring septic peritonitis in rats: effect of polyethylene glycol-absorbed superoxide dismutase / N. Fujimura, S. Sumita, E. Narimatsu // Critical Care Medicine. - 2000. Vol. 28, № 7. - P. 2406-1414.

11. Abdominal compartment syndrome in patients with isolated extraperitoneal injuries / T. Kopelman, C. Harris, R. Miller, A. Arrillaga // J. Trauma. - 2000. Vol. 49. - P. 744-749.

12. The enigma of sepsis / C. Niels, R. Riedmann, RenFeng Guo, P. A. Ward // J. Clin. Invest. - 2003. - № 12. P. 460-467.

\section{FUNCTIONAL FEATURES OF THE KIDNEY AND LIVER VASCULAR BED IN ACUTE DIFFUSE PERITONITIS AND ITS COMPLICATIONS}

\section{Horbachevsky Ternopil State Medical University}

๑A. V. Hantimurov

SUMMARY. The article provides manifestation overview of morphofunctional reaction of blood vessels of the kidneys and liver in the dynamics of acute diffuse peritonitis and its complications.

The features of functional changes of the vascular bed of the kidneys and liver, resulting from the effects of toxic metabolic products that enter to the bloodstream from abdominal cavity were identified. Increase of intra-abdominal pressure, which occurs during the progression of acute diffuse peritonitis as one of the major causes of occurrence of disorders of general and organ hemodynamics was noted.

KEY WORDS: peritonitis, blood vessels, kidneys, liver. 